\title{
Respon dan Produktivitas Padi Rawa terhadap Cekaman Rendaman Stagnan untuk Pengembangan di Lahan Rawa Lebak
}

\author{
Response and Productivity of Swampy Rice to Stagnant \\ Flooding Stress for Improvement on Basin Swampy Area
}

\author{
Yullianida $^{1,2}$, Sintho Wahyuning Ardie ${ }^{3}$, Suwarno $^{2}$, dan Hajrial Aswidinnoor ${ }^{3 *}$ \\ ${ }^{1}$ Program Studi Pemuliaan dan Bioteknologi Tanaman, Sekolah Pascasarjana, Institut Pertanian Bogor \\ ${ }^{2}$ Balai Besar Penelitian Tanaman Padi (Indonesia Center for Rice Research) \\ Kebun Percobaan Muara, Jl. Raya Ciapus No. 25A Bogor Barat 16119, Indonesia \\ ${ }^{3}$ Departemen Agronomi dan Hortikultura, Fakultas Pertanian, Institut Pertanian Bogor \\ (Bogor Agricultural University), Jl. Meranti, Kampus IPB Darmaga, Bogor 16680, Indonesia
}

Diterima 20 Maret 2014/Disetujui 21 Juli 2014

\begin{abstract}
The limited fertile land and increasing flood intensity as a result of global climate changes become serious constraints in the sustainability of national rice production. Improvement of rice varieties, especially for rice cultivation in swampy area is necessary. The objective of this research were to evaluate responses and productivity of rice genotypes to stagnant flooding stress which occurs on swampy area. A total of 22 genotypes had been tested, included Tapus, IR42, and IR64 as check varieties. Water level at stagnant flooding environment was 50-60 cm and started from 35 days after planting until harvest. Research was conducted in wet season of 2011/2012 at Babakan Experimental Farm, Bogor Agricultural University. The experiment used randomized block design with three replicates. The results showed that stagnant flooding stress caused an increase in plant height, flowering and maturity date, number of unfilled grain, and stem elongation ability. On the other hand, the number of productive tiller and the number of filled grain decreased. The number of filled grain positively correlated with grain yield $\left(r=0.74^{* *}\right)$, but stem elongation ability didn't have strong correlation with grain yield $(r=-$ 0.29). Genotypes IPB107-F-5-1-1 and IPB107-F-82-2-1 showed the highest productivity, 5.47 ton ha and $^{-1} .80$ ton ha-1, respectively, at which productivity decreased up to $20 \%$ compared to optimum condition.
\end{abstract}

Keywords: basin swampy rice, stagnant flooding

\section{ABSTRAK}

Keterbatasan lahan subur dan peningkatan intensitas banjir akibat perubahan iklim global menjadi kendala dalam produksi padi nasional. Diperlukan ekstensifikasi ke lahan rawa menggunakan varietas toleran rendaman, terutama lahan rawa lebak yang selama ini belum termanfaatkan. Tujuan penelitian ini adalah untuk mengetahui respon dan produktivitas tanaman padi terhadap cekaman rendaman stagnan yang kerap terjadi pada lahan rawa lebak. Sebanyak 22 genotipe, termasuk tiga varietas pembanding (Tapus, IR42, dan IR64) diuji toleransinya terhadap cekaman rendaman stagnan setinggi 50-60 cm dari permukaan tanah, mulai 35 hari setelah semai sampai dengan panen. Penelitian dilakukan pada musim hujan 2011/2012 di Kebun Percobaan Babakan, Institut Pertanian Bogor. Hasil penelitian menunjukkan bahwa respon tanaman padi terhadap cekaman rendaman stagnan berupa peningkatan tinggi tanaman, umur berbunga dan panen, jumlah gabah hampa, dan pemanjangan batang, sedangkan jumlah anakan produktif dan jumlah gabah isi berkurang jika dibanding tanaman padi yang ditanam pada lingkungan optimum (sawah). Jumlah gabah isi berkorelasi nyata positif terhadap hasil ( $\left.r=0.74^{* *}\right)$, namun tidak demikian dengan kemampuan pemanjangan batang ( $r=-0.29)$. Genotipe IPB107-F-5-1-1 dan IPB107-F-82-2-1 menunjukkan produktivitas tertinggi pada lingkungan tercekam rendaman stagnan, masing-masing sebesar 5.47 ton ha-1 dan 5.80 ton $\mathrm{ha}^{-1}$ dengan penurunan produktivitas kurang dari $20 \%$ jika dibanding dengan lingkungan optimum.

Kata kunci: padi rawa lebak, rendaman stagnan

\footnotetext{
* Penulis untuk korespondensi. e-mail: hajrial@gmail.com
} 


\section{PENDAHULUAN}

Pemanasan global yang terjadi pada beberapa tahun belakangan memicu peningkatan resiko banjir. Menurut Hirabayashi et al. (2013) peningkatan frekuensi banjir tergantung pada peningkatan derajat pemanasan global yang terjadi dan tertinggi adalah di Asia Tenggara, India, Afrika Timur dan Utara Pegunungan Andes. Cekaman rendaman atau genangan dapat menghambat pertumbuhan dan perkembangan tanaman dengan terjadinya penurunan komponen hasil dan hasil tanaman. Kuswantoro (2011) menyatakan pada tanaman kedelai bahwa cekaman rendaman menyebabkan penurunan jumlah cabang produktif, jumlah polong isi dan hasil. Pada tanaman padi, telah banyak dilaporkan dampak cekaman rendaman terhadap pertumbuhan dan hasil, namun lebih terbatas pada cekaman rendaman keseluruhan yang sesaat seperti akibat terjadinya banjir rob. Para peneliti dari IRRI juga sudah banyak mempublikasikan hasil penelitian terkait cekaman rendaman keseluruhan, antara lain (1) Septiningsih et al. (2009) yang mengungkapkan pembentukan tanaman padi toleran cekaman rendaman keseluruhan melalui pendekatan molekuler dengan penemuan gen Subl dan (2) Mackill et al. (2010) mempelajari cekaman rendaman sebagai salah satu cara adaptasi untuk antisipasi perubahan iklim global. Dengan semakin tingginya intensitas banjir dan cekaman rendaman, Collard et al. (2013) menyatakan perlu upaya perakitan varietas toleran rendaman untuk berbagai kondisi rendaman yang terjadi sekarang ini, seperti rendaman stagnan, rendaman pada fase kecambah (anaerobic germination), serta gabungan berbagai cekaman abiotik terkait cekaman rendaman, seperti salinitas dan kekeringan.

Perakitan varietas padi yang toleran terhadap rendaman keseluruhan dan sesaat (submergence/flash flooding) telah berkembang baik dengan ditemukannya gen Subl yang dimasukkan ke beberapa varietas berdaya hasil tinggi di Asia yang ditanam lebih dari satu juta hektar antara lain IR64, Swarna, Samba Mahsuri BR11, TDK dan CR1009 (Septiningsih et al., 2009). Metode pemuliaan yang digunakan adalah metode silang balik dengan bantuan marka molekuler atau marker assisted backcrossing (MAB). Selain gen Sub1, saat ini telah ditemukan gen Snorkel1 dan Snorkel2 yang mengendalikan sifat kemampuan pemanjangan batang ketika tanaman padi tercekam rendaman. Gen Snorkel sesuai untuk pertanaman padi yang mengalami cekaman rendaman stagnan atau berada di daerah rawa dalam (deepwater). Tiga QTL (quantitative trait locci) yang berperan dalam kemampuan pemanjangan batang terletak pada kromosom 1, 3 dan 12 (Hattori et al., 2008). Diantara ketiga lokus tersebut, gen pengendali pada kromosom 12 adalah yang paling utama. Penemuan tersebut memungkinkan untuk menggunakan pendekatan molekuler dalam perbaikan kemampuan pemanjangan batang varietas padi untuk toleransi terhadap rendaman stagnan. Sedangkan menurut Nugraha et al. (2013) bobot tajuk, bobot daun, luas indek daun, diameter batang, tinggi tanaman dan jumlah anakan merupakan karakter yang paling efektif digunakan sebagai kriteria untuk seleksi tandem terhadap hasil gabah karena memiliki variabilitas genetik luas, heritabilitas tinggi dan korelasi yang kuat dengan hasil gabah. Karakterkarakter tersebut efektif digunakan untuk seleksi hasil gabah padi yang toleran terhadap cekaman rendaman stagnan.

Cekaman rendaman stagnan pada pertanaman padi sering terjadi pada daerah rawa lebak. Penggunaan varietas lokal di lahan rawa lebak masih memberikan produktivitas yang rendah, seperti Pandak Putih dan Siam Kuning di lahan rawa lebak dalam Kalimantan Selatan hanya sekitar 3.0 ton $\mathrm{ha}^{-1}$ dan Sei Putih di lebak pematang dan tengahan Sumatera Selatan berkisar 2.0-2.5 ton ha-1 (Suwarno et al., 1996). Penggunaan varietas unggul baru (VUB) berdampak terhadap peningkatan produktivitas, antara lain varietas Cisanggarung pada musim kemarau di Kayu Agung, Sumatera Selatan dapat menghasilkan 4.0-5.5 ton $\mathrm{ha}^{-1}$, varietas unggul padi seperti Barito, Mahakam, Tapus, Alabio dan Nagara mampu menghasilkan gabah kering giling sebanyak 4.0-5.0 ton ha-1 di lahan lebak dangkal dan tengahan Kayuagung, Sumatera Selatan (Suwarno et al., 1996). Terlihat bahwa jika budidaya padi lebak dilakukan secara intensif, maka daerah tersebut memiliki potensi yang tinggi sebagai alternatif sentra produksi padi.

IRRI (International Rice Research Institute) mulai melirik pengembangan area pertanaman padi ke lahanlahan yang mengalami cekaman rendaman stagnan, yaitu terendam $25-50 \mathrm{~cm}$ dari permukaan tanah selama hampir seluruh fase hidupnya. Belum ada varietas padi yang dilepas untuk kondisi terendam seperti ini. Selain itu, perakitan varietas padi yang memiliki kombinasi toleransi terhadap rendaman sesaat dan stagnan merupakan prioritas utama program pemuliaan di IRRI. Beberapa galur harapan yang memiliki toleransi terhadap kedua jenis rendaman tersebut telah diuji lapang di Asia dan Afrika selama tahun 20112012 (Mackill et al., 2010).

Tujuan penelitian ini adalah mempelajari respon genotipe padi terhadap cekaman rendaman stagnan dan mengevaluasi karakter yang paling berkontribusi terhadap hasil.

\section{BAHAN DAN METODE}

Materi genetik yang digunakan terdiri atas 19 genotipe padi rawa dengan tiga varietas pembanding (Tabel 1). Varietas pembanding yang digunakan yaitu varietas Tapus sebagai pembanding yang memiliki kemampuan membentuk buku dan sesuai untuk pertanaman di lahan rawa lebak dan varietas IR64 dan IR42 sebagai pembanding padi sawah.

Penelitian dilaksanakan pada musim hujan (MH) 2011/2012, mulai bulan Oktober 2011 sampai dengan Februari 2012 di Kebun Percobaan Babakan-Institut Pertanian Bogor. Terdapat dua lingkungan pengujian, yaitu lingkungan tercekam rendaman stagnan dan lingkungan optimum (sawah). Cekaman rendaman yang diberikan bersifat stagnan, yaitu mulai 35 hari setelah semai (HSS) hingga panen, namun hanya sebagian tanaman berada di bawah permukaan air (stagnant partial flooding) dengan ketinggian air 50-60 cm. Rancangan yang digunakan pada tiap lingkungan adalah rancangan acak kelompok (RAK) dengan tiga ulangan. 
Tabel 1. Materi genetik yang digunakan beserta asal persilangannya

\begin{tabular}{|c|c|c|}
\hline & Genotipe & Asal tetua \\
\hline G1 & IR41410-6-3-3-1-2 & Introduksi dari IRRI (elongation type) \\
\hline $\mathrm{G} 2$ & IR28273-3R-29-38-1-1-3 & Introduksi dari IRRI \\
\hline G3 & B11586F-MR-11-2-2 & Mesir/IR600-80-23 \\
\hline G4 & B10580E-KN-81-3 & Batutegi/Kapuas \\
\hline G5 & BP1027F-PN-1-2-1-KN-MR-3-3 & Pucuk/IR64 \\
\hline G6 & B10217F-TB-38-1-1 & Pontianak/Sita//IR42 \\
\hline G7 & B13132-8-MR-1-KA-1 & Kapuas/IR73571-3B-R-2-2-3-1//IR69502-6-SKN-UBN-1-B-1-3/CNA2903 \\
\hline G8 & B13134-4-MR-1-KA-1 & Kapuas/IR73571-3B-R-2-2-3-1 //Dendang /KAL9418F-MR-2 \\
\hline G9 & B13135-1-MR-2-KA-1 & Mahsuri/Cimelati//IR69502-6-SKN-UBN-1-B-1-3/Bondoyudo \\
\hline G10 & B13138-7-MR-2-KA-1 & IR69502-6-SKN-UBN-1-B-1-3 / KAL9418F //Pokhali/Angke \\
\hline G11 & B13138-7-MR-2-KA-2 & IR69502-6-SKN-UBN-1-B-1-3 / KAL9418F //Pokhali/Angke \\
\hline G12 & IPB107-F-16-2-1 & Siam Sapat/Fatmawati \\
\hline G13 & IPB107-F-5-1-1 & Siam Sapat/Fatmawati \\
\hline G14 & IPB107-F-27-6-1 & Siam Sapat/Fatmawati \\
\hline G15 & IPB107-F-82-2-1 & Siam Sapat/Fatmawati \\
\hline G16 & IPB107-F-60-1-1 & Siam Sapat/Fatmawati \\
\hline G17 & IPB107-F-95-1-1 & Siam Sapat/Fatmawati \\
\hline G18 & IPB107-F-127-3-1 & Siam Sapat/Fatmawati \\
\hline G19 & IPB 107-F-13-1-1 & Siam Sapat/Fatmawati \\
\hline G20 & Tapus (Padi Lebak) & IR36/Leb Mue Nahng III \\
\hline G21 & IR64 (Padi Sawah) & IR5657/IR2061 \\
\hline $\mathrm{G} 22$ & IR42 (Padi Sawah) & IR1561-228-1-2/IR1737//CR94-13 \\
\hline
\end{tabular}

\section{Pelaksanaan Percobaan}

Benih per genotipe disemai pada tempat pembibitan dan setelah bibit berumur 21 HSS khusus untuk perlakuan pada lingkungan tercekam rendaman bibit kemudian dipindah tanam ke dalam polibag, sedangkan untuk lingkungan optimum bibit langsung ditanam di lahan sawah. Penanaman pada lingkungan optimum adalah setiap galur ditanam sebanyak dua baris dengan masing-masing galur terdapat 30 tanaman per ulangan. Penanaman pada lingkungan tercekam rendaman yaitu penanaman bibit tidak dilakukan langsung di dasar kolam karena pada awal rendaman sulit mengeluarkan sebagian air dari dalam kolam. Ketinggian permukaan air kolam masih terlalu tinggi untuk bibit berumur 21 HSS sehingga dapat dipastikan seluruh bagian tanaman terendam secara keseluruhan. Padahal cekaman rendaman yang diberikan adalah parsial stagnan, yaitu hanya $40-99 \%$ bagian tanaman yang terendam air. Rendaman dilakukan dua minggu setelah tanam (35 HSS).

Karakter yang diamati meliputi panjang batang, tinggi tanaman, jumlah anakan produktif, umur berbunga $50 \%$, umur panen $80 \%$, jumlah gabah isi per malai, jumlah gabah hampa per malai, bobot 1,000 butir gabah dan hasil. Pengukuran pemanjangan batang padi dilakukan tiga kali, yaitu pada fase vegetatif, generatif, dan menjelang panen untuk mengetahui laju pemanjangan batang.
Analisis Data

Data pada lingkungan tercekam rendaman stagnan dan lingkungan optimum dianalisis menggunakan sidik ragam, apabila terdapat pengaruh nyata, maka dilanjutkan dengan uji Beda Nyata Terkecil (BNT) pada taraf 5\%. Perbedaan antara lingkungan tercekam rendaman dan lingkungan optimum pada tiap karakter yang diamati diuji dengan uji-t. Selain itu, dilakukan analisis korelasi antar karakter yang diamati terhadap hasil gabah.

\section{HASIL DAN PEMBAHASAN}

Karakter Agronomi Padi pada Lingkungan Tercekam Rendaman Stagnan

Hasil pengamatan terhadap karakter agronomi yang meliputi tinggi tanaman, jumlah anakan produktif, umur berbunga $50 \%$ dan umur panen $80 \%$ disajikan pada Tabel 2. Berdasarkan hasil uji-t, semua karakter agronomi yang diamati pada lingkungan tercekam rendaman stagnan berbeda sangat nyata $(\mathrm{P}<0.01)$ dengan lingkungan optimum. Penanaman pada lingkungan tercekam rendaman stagnan menunjukkan bahwa terdapat 12 genotipe yang memiliki tinggi tanaman diatas varietas pembanding Tapus (G20), namun delapan genotipe di antaranya tidak berbeda nyata. 
Genotipe yang memiliki tinggi tanaman tertinggi adalah IR41410-6-3-3-1-2 (G1) setinggi $156 \mathrm{~cm}$ yang merupakan introduksi dari IRRI dan terkarakterisasi memiliki kemampuan pemanjangan batang (elongation type), sedangkan yang terendah adalah IR28273-3R-29-38-1-1-3 (G2) setinggi $101.7 \mathrm{~cm}$ yang juga merupakan introduksi dari IRRI dan tidak berbeda nyata dengan varietas pembanding padi sawah IR64 (21) setinggi $105 \mathrm{~cm}$ dan IR42 (G22) setinggi $101.6 \mathrm{~cm}$. Apabila dibandingkan dengan tinggi tanaman pada lingkungan optimum, cekaman rendaman stagnan terlihat menyebabkan pertambahan tinggi tanaman. Menurut Singh et al. (2011) cekaman rendaman stagnan dengan ketinggian air $30 \mathrm{~cm}$ dan $50 \mathrm{~cm}$ menyebabkan pertambahan tinggi tanaman masing-masing sebesar $13 \%$ dan $17 \%$.

Jumlah anakan produktif pada lingkungan tercekam rendaman stagnan terlihat mengalami penurunan apabila dibandingkan dengan lingkungan optimum (Tabel 2).
Jumlah anakan produktif varietas IR64 (G21) tidak berbeda nyata dengan varietas pembanding Tapus (G20) dan varietas pembanding IR42 (G22) pada lingkungan tercekam rendaman stagnan. Pada lingkungan optimum, jumlah anakan produktif galur-galur padi rawa berkisar antara 912 anakan per rumpun dan 11 genotipe diantaranya tidak berbeda nyata dengan varietas Tapus (G20), sedangkan varietas padi sawah IR64 (G21) dan IR42 (G22) mempunyai jumlah anakan terbanyak masing-masing 13 dan 16 anakan per rumpun. Jumlah anakan yang sedikit pada galur IPB107F (G12-G19) kemungkinan terkait sifat genetik dari galurgalur tersebut yang merupakan turunan dari padi tipe baru Fatmawati yang jumlah anakannya sedikit.

Cekaman rendaman stagnan menyebabkan umur berbunga dan umur panen menjadi lebih lama pada seluruh genotipe yang diuji (Tabel 2). Namun perbedaan umur berbunga $50 \%$ dan umur panen $80 \%$ paling menonjol terjadi pada varietas pembanding IR42 (G22), masing-masing selama 10 hari dan 12 hari.

Tabel 2. Karakter agronomi padi pada lingkungan tercekam rendaman stagnan (LR) dan lingkungan optimum (LO), KP. Babakan, MH 2011/2012

\begin{tabular}{|c|c|c|c|c|c|c|c|c|}
\hline \multirow{2}{*}{ Genotipe } & \multicolumn{2}{|c|}{ TT (cm) } & \multicolumn{2}{|c|}{ JAP } & \multicolumn{2}{|c|}{ UB (HSS) } & \multicolumn{2}{|c|}{ UP (HSS) } \\
\hline & LR & $\mathrm{LO}$ & LR & LO & LR & $\mathrm{LO}$ & LR & LO \\
\hline G1 & $156.0 \mathrm{a}$ & $139.1 \mathrm{a}$ & $10.0 \mathrm{ab}$ & $11.3 \mathrm{~cd}$ & $94 c$ & $86 \mathrm{e}$ & $124 c$ & $115 \mathrm{~d}$ \\
\hline $\mathrm{G} 2$ & $101.7 \mathrm{j}$ & $105.1 \mathrm{i}$ & $8.3 \mathrm{bcd}$ & $10.3 \mathrm{cdefg}$ & $88 \mathrm{~g}$ & $84 \mathrm{~g}$ & $118 \mathrm{~g}$ & $115 \mathrm{~d}$ \\
\hline G3 & $130.0 \mathrm{de}$ & $116.1 \mathrm{~b}$ & $10.3 \mathrm{a}$ & $9.3 \mathrm{fgh}$ & $86 \mathrm{i}$ & $81 \mathrm{j}$ & $116 \mathrm{i}$ & $113 \mathrm{f}$ \\
\hline G4 & $116.7 \mathrm{~h}$ & 107.0hi & 5.7ghij & 9.7efgh & $90 \mathrm{e}$ & $88 c$ & $120 \mathrm{e}$ & $116 c$ \\
\hline G5 & $136.3 \mathrm{bc}$ & $116.7 \mathrm{~b}$ & 7.0defg & $10.3 \mathrm{cdefg}$ & $92 d$ & $86 \mathrm{e}$ & $122 d$ & $115 \mathrm{~d}$ \\
\hline G6 & $122.3 \mathrm{fg}$ & $107.8 \mathrm{~h}$ & 6.3efgh & 10.0defg & $89 f$ & $83 \mathrm{~h}$ & $119 f$ & $114 \mathrm{e}$ \\
\hline G7 & $110.7 \mathrm{i}$ & $105.1 \mathrm{i}$ & 6.0fghi & $11.3 \mathrm{~cd}$ & $89 f$ & $84 \mathrm{~g}$ & $119 f$ & $113 f$ \\
\hline G8 & $122.0 \mathrm{fg}$ & $101.6 \mathrm{j}$ & 6.3efgh & $11.7 \mathrm{c}$ & $98 b$ & $92 b$ & $127 b$ & $120 \mathrm{~b}$ \\
\hline G9 & $125.7 \mathrm{ef}$ & $116.4 b$ & $10.0 \mathrm{ab}$ & $11.3 \mathrm{~cd}$ & $90 \mathrm{e}$ & $82 \mathrm{i}$ & $120 \mathrm{e}$ & $113 f$ \\
\hline G10 & $116.7 \mathrm{~h}$ & $110.7 \mathrm{cde}$ & 7.7cdef & $11.3 \mathrm{~cd}$ & $86 \mathrm{i}$ & 781 & $116 \mathrm{i}$ & $109 \mathrm{j}$ \\
\hline G11 & $121.3 \mathrm{fgh}$ & $112.8 \mathrm{c}$ & $8.0 \mathrm{cde}$ & $8.3 \mathrm{~h}$ & $90 \mathrm{e}$ & $85 f$ & $120 \mathrm{e}$ & $115 d$ \\
\hline G12 & $119.7 \mathrm{gh}$ & $110.4 \mathrm{cdef}$ & $4.0 \mathrm{jk}$ & $8.7 \mathrm{gh}$ & $87 \mathrm{~h}$ & $80 \mathrm{k}$ & $117 \mathrm{~h}$ & $110 \mathrm{i}$ \\
\hline G13 & $111.3 \mathrm{i}$ & $107.9 \mathrm{gh}$ & $8.0 \mathrm{cde}$ & 9.7efgh & $86 \mathrm{i}$ & $83 \mathrm{~h}$ & $116 \mathrm{i}$ & $112 \mathrm{~g}$ \\
\hline G14 & $119.0 \mathrm{gh}$ & $108.8 \mathrm{efgh}$ & 7.0defg & $8.3 \mathrm{~h}$ & $85 \mathrm{j}$ & $83 \mathrm{~h}$ & $115 \mathrm{j}$ & $113 \mathrm{f}$ \\
\hline G15 & $131.7 \mathrm{~cd}$ & $110.6 \mathrm{cde}$ & 5.0hij & $9.3 \mathrm{fgh}$ & $87 \mathrm{~h}$ & $81 \mathrm{j}$ & $117 \mathrm{~h}$ & $111 \mathrm{~h}$ \\
\hline G16 & $129.7 \mathrm{de}$ & 109.0efgh & 6.7defgh & $8.3 \mathrm{~h}$ & $86 \mathrm{i}$ & $83 \mathrm{~h}$ & $115 \mathrm{j}$ & $111 \mathrm{~h}$ \\
\hline G17 & $132.7 \mathrm{bcd}$ & $110.2 \mathrm{defg}$ & $7.3 \mathrm{cdefg}$ & $11.0 \mathrm{cde}$ & $87 \mathrm{~h}$ & $86 \mathrm{e}$ & $116 \mathrm{i}$ & $113 \mathrm{f}$ \\
\hline G18 & $134.0 \mathrm{bcd}$ & $112.0 \mathrm{~cd}$ & $9.0 \mathrm{abc}$ & $9.3 \mathrm{fgh}$ & $85 \mathrm{j}$ & $82 \mathrm{i}$ & $114 \mathrm{k}$ & $111 \mathrm{~h}$ \\
\hline G19 & $137.3 b$ & $115.2 b$ & 7.0defg & $9.3 \mathrm{fgh}$ & $86 \mathrm{i}$ & $84 \mathrm{~g}$ & 1131 & $112 \mathrm{~g}$ \\
\hline G20 & 120. $7 \mathrm{fgh}$ & $108.1 \mathrm{fgh}$ & $5.7 \mathrm{ghij}$ & $8.7 \mathrm{gh}$ & $88 \mathrm{~g}$ & $87 d$ & $116 \mathrm{i}$ & $115 d$ \\
\hline $\mathrm{G} 21$ & $105.0 \mathrm{j}$ & $96.2 \mathrm{k}$ & $4.3 \mathrm{ijk}$ & $13.3 b$ & $87 \mathrm{~h}$ & $82 \mathrm{i}$ & $117 \mathrm{~h}$ & $112 \mathrm{~g}$ \\
\hline G22 & $101.6 \mathrm{j}$ & 91.411 & $3.0 \mathrm{k}$ & $15.7 \mathrm{a}$ & $106 a$ & $96 a$ & $132 \mathrm{a}$ & $124 \mathrm{a}$ \\
\hline BNT & 5.3 & 2.37 & 1.86 & 1.60 & 0 & 0 & 0 & 0 \\
\hline r Hasil & 0.09 & -0.04 & -0.09 & -0.15 & $-0.51 * *$ & -0.16 & -0.57 & -0.22 \\
\hline
\end{tabular}

Keterangan: Angka yang diikuti huruf yang sama pada kolom yang sama tidak berbeda nyata berdasarkan uji beda nyata terkecil (BNT) pada taraf 5\%; TT = tinggi tanaman; JAP = jumlah anakan produktif per rumpun; $\mathrm{UB}=$ umur berbunga 50\%; $\mathrm{UP}=$ umur panen $80 \%$; r Hasil $=$ koefisien korelasi terhadap hasil; $* *=$ berkorelasi sangat nyata; HSS $=$ hari setelah semai 


\section{Kemampuan Pemanjangan Batang Padi}

Strategi adaptasi tanaman padi terhadap cekaman rendaman stagnan adalah melakukan pemanjangan batang mengikuti naiknya permukaan air, sehingga daun masih berada di atas permukaan air untuk menghindari kondisi anaerob. Hattori et al. (2011) menyebutkan strategi ini sebagai escape strategy. Menurut Hattori et al. (2009) pada bagian tanaman yang terendam air, zat pengatur tumbuh (ZPT) etilen terakumulasi sehingga mengalami peningkatan yang menginduksi ekspresi gen Snorkell (SK1) dan Snorkel2 (SK2) yang berfungsi sebagai ERF-type transcription factors. Selain itu terjadi juga peningkatan ZPT gibberellic acid (GA). Namun pada penelitian ini tidak diamati peranan kedua ZPT tersebut.

Pengamatan pada penelitian ini dilakukan tiga kali terhadap kemampuan pemanjangan batang, yaitu pada fase vegetatif (37 HSS), fase generatif (80 HSS) dan menjelang panen (91 HSS). Tabel 3 menunjukkan bahwa laju pemanjangan batang berlangsung cepat pada awal perendaman dan menurun seiring dengan waktu perendaman. Laju pemanjangan batang tertinggi terjadi pada genotipe IR41410-6-3-3-1-2 (G1), yaitu sebesar $1.6 \mathrm{~cm}$ hari $^{-1}$ karena merupakan genotipe introduksi dari IRRI yang memiliki elongation type. Genotipe B10580E-KN-81-3 (G4) memiliki laju pemanjangan batang kedua tertinggi, yaitu sebesar $1.4 \mathrm{~cm}_{\text {hari }}{ }^{-1}$. Penelitian sebelumnya menunjukkan bahwa galur tersebut mempunyai laju pemanjangan batang tertinggi setara dengan varietas Margasari dan lebih tinggi dibandingkan varietas pembanding Tapus (Yullianida et al., 2011).

Selisih pemanjangan batang yang terjadi pada genotipe B10580E-KN-81-3 (G4) pada awal pengamatan (fase vegetatif) dan akhir pengamatan (menjelang panen) sebesar $42.3 \mathrm{~cm}$, lebih rendah dibandingkan beberapa genotipe lainnya, kecuali dari galur B13138-7-MR-2KA-1 (G10), IPB107F-27-6-1 (G14) dan IPB107F-60-1-1 (G16). Penyebabnya adalah pemanjangan batang sangat cepat terjadi pada fase vegetatif $\left(1.7 \mathrm{~cm} \mathrm{hari}^{-1}\right)$, sedangkan pada fase generatif dan menjelang panen lajunya menurun

Tabel 3. Pemanjangan batang padi pada lingkungan tercekam rendaman stagnan, Kebun Percobaan Babakan, MH $2011 / 2012$

\begin{tabular}{|c|c|c|c|c|c|c|c|c|}
\hline \multirow[t]{2}{*}{ Genotipe } & \multicolumn{4}{|c|}{$\begin{array}{l}\text { Laju pemanjangan batang } \\
(\mathrm{cm} \mathrm{hari-1})\end{array}$} & \multicolumn{3}{|c|}{$\begin{array}{c}\text { Panjang batang pada } 3 \text { fase pertumbuhan } \\
(\mathrm{cm})\end{array}$} & \multirow{2}{*}{$\begin{array}{c}\text { Kemampuan } \\
\text { pemanjangan } \\
\text { batang }(\mathrm{cm})\end{array}$} \\
\hline & I & II & III & Rata-rata & I & II & III & \\
\hline G1 & 1.8 & 1.5 & 1.4 & 1.6 & 67.1 & 122.3 & 131.7 & 64.6 \\
\hline G2 & 1.2 & 1.1 & 1.0 & 1.1 & 43.3 & 86.7 & 92.7 & 49.3 \\
\hline G3 & 1.5 & 1.3 & 1.2 & 1.3 & 55.7 & 101.3 & 108.0 & 52.3 \\
\hline G4 & 1.7 & 1.2 & 1.2 & 1.4 & 62.3 & 97.3 & 104.7 & 42.3 \\
\hline G5 & 1.5 & 1.3 & 1.2 & 1.3 & 54.3 & 107.7 & 111.7 & 57.3 \\
\hline G6 & 1.2 & 1.2 & 1.1 & 1.2 & 45.7 & 98.7 & 100.7 & 55.0 \\
\hline G7 & 1.3 & 1.2 & 1.2 & 1.2 & 47.3 & 95.0 & 105.0 & 57.7 \\
\hline G8 & 1.4 & 1.0 & 1.1 & 1.2 & 50.7 & 79.7 & 100.0 & 49.3 \\
\hline G9 & 1.4 & 1.2 & 1.2 & 1.3 & 51.7 & 96.0 & 109.3 & 57.7 \\
\hline G10 & 1.4 & 1.1 & 1.0 & 1.2 & 52.7 & 87.0 & 87.3 & 34.7 \\
\hline G11 & 1.4 & 1.1 & 1.0 & 1.2 & 50.7 & 90.3 & 94.7 & 44.0 \\
\hline G12 & 1.4 & 1.1 & 1.0 & 1.2 & 53.0 & 91.0 & 95.0 & 42.0 \\
\hline G13 & 1.6 & 1.0 & 1.0 & 1.2 & 57.7 & 82.0 & 95.0 & 37.3 \\
\hline G14 & 1.6 & 1.1 & 1.0 & 1.2 & 57.7 & 87.0 & 90.0 & 32.3 \\
\hline G15 & 1.5 & 1.0 & 1.1 & 1.2 & 53.7 & 82.0 & 98.0 & 44.3 \\
\hline G16 & 1.5 & 1.1 & 1.0 & 1.2 & 56.7 & 86.0 & 90.0 & 33.3 \\
\hline G17 & 1.6 & 1.2 & 1.2 & 1.3 & 60.7 & 96.7 & 105.0 & 44.3 \\
\hline G18 & 1.5 & 1.2 & 1.1 & 1.3 & 54.7 & 99.0 & 100.7 & 46.0 \\
\hline G19 & 1.5 & 1.2 & 1.1 & 1.3 & 56.0 & 99.7 & 101.3 & 45.3 \\
\hline G20 & 1.4 & 1.2 & 1.1 & 1.2 & 52.0 & 95.7 & 97.0 & 45.0 \\
\hline G21 & 1.2 & 0.9 & 0.9 & 1.0 & 45.7 & 75.7 & 85.0 & 39.3 \\
\hline G22 & 1.3 & 0.9 & 0.9 & 1.0 & 48.3 & 72.3 & 85.0 & 36.7 \\
\hline r Hasil & & & & -0.11 & & & & -0.29 \\
\hline
\end{tabular}

Keterangan: $\mathrm{I}$ = fase vegetatif $(37 \mathrm{HSS})$; II = fase generatif $(80 \mathrm{HSS}) ; \mathrm{III}=$ menjelang panen $(91 \mathrm{HSS})$; dan $\mathrm{r}$ Hasil = korelasi terhadap hasil 
(1.2 $\left.\mathrm{cm} \mathrm{hari}^{-1}\right)$. Lain halnya dengan genotipe IR41410-6-33-1-2 (G1) yang memiliki laju pemanjangan batang yang relatif tinggi pada semua fase pertumbuhan, yaitu $1.8 \mathrm{~cm}$ hari $^{-1}$ pada fase vegetatif ( $37 \mathrm{HSS}$ ), $1.5 \mathrm{~cm} \mathrm{hari}^{-1}$ pada fase generatif (80 HSS) dan $1.4 \mathrm{~cm} \mathrm{hari}^{-1}$ pada saat menjelang panen (91 HSS), sehingga selisih pemanjangan batangnya pun menjadi tinggi.

\section{Komponen Hasil dan Produktivitas Tanaman Padi}

Hasil gabah pada cekaman rendaman merupakan fungsi dari kemampuan tanaman padi untuk membentuk kapasitas lumbung (sink) di antaranya anakan produktif, ukuran malai dan persentase gabah isi malai (Mallik et al., 2004). Komponen hasil yang diamati pada percobaan ini meliputi jumlah gabah isi dan hampa per malai, serta bobot 1,000 butir gabah (Tabel 4). Cekaman rendaman stagnan menyebabkan penurunan jumlah gabah isi lebih dari 50\% pada semua genotipe yang diuji, kecuali varietas IR64
(G21), sedangkan pada varietas IR42 (G22) mengalami penurunan gabah isi hampir $80 \%$ apabila dibandingkan dengan lingkungan optimum. Terdapat empat genotipe yang memiliki jumlah gabah isi tidak berbeda nyata dengan varietas Tapus, yaitu IPB107-F-16-2-1 (G12), IPB107F-601-1 (G16), IPB107F-13-1-1 (G19) dan IR64 (G21).

Cekaman rendamanstagnanmenyebabkan peningkatan jumlah gabah hampa. Jumlah gabah hampa paling rendah terdapat pada genotipe IPB107-F-13-1-1 (G19) sebanyak 57 butir. Varietas pembanding IR64 (G21) mempunyai jumlah gabah hampa yang sangat rendah, baik pada lingkungan tercekam rendaman stagnan maupun lingkungan optimum. Bobot 1,000 butir gabah berkisar antara 25-28 g, kecuali untuk varietas IR42 (G22) yang memang memiliki ukuran gabah kecil (Tabel 4). Cekaman rendaman stagnan tidak menyebabkan perubahan ukuran gabah.

Cekaman rendaman stagnan menyebabkan penurunan hasil pada semua genotipe yang diuji. Penurunan hasil terendah terjadi pada genotipe BP1027F-PN-1-2-1-KN-

Tabel 4. Komponen hasil dan hasil gabah pada lingkungan tercekam rendaman stagnan (LR) dan lingkungan optimum (LO), KP. Babakan, MH 2011/2012

\begin{tabular}{|c|c|c|c|c|c|c|c|c|c|}
\hline \multirow{2}{*}{ Genotipe } & \multicolumn{2}{|c|}{ GI } & \multicolumn{2}{|c|}{ GH } & \multicolumn{2}{|c|}{$\mathrm{B} 1,000(\mathrm{~g})$} & \multicolumn{2}{|c|}{ HSL $\left(\right.$ ton $\left.\mathrm{ha}^{-1}\right)$} & \multirow{2}{*}{$\Delta \mathrm{HSL}(\%)$} \\
\hline & LR & $\mathrm{LO}$ & $\overline{L R}$ & LO & LR & $\mathrm{LO}$ & $\overline{L R}$ & LO & \\
\hline$\overline{\text { G1 }}$ & $23 \mathrm{gh}$ & 93ijk & $178 \mathrm{bcd}$ & 48hijk & $25.11 \mathrm{j}$ & $25.05 j$ & $2.26 \mathrm{jk}$ & $4.60 \mathrm{ef}$ & 50.87 \\
\hline G2 & $18 \mathrm{gh}$ & $83 \mathrm{k}$ & $157 \mathrm{cde}$ & $70 \mathrm{fg}$ & $26.35 \mathrm{efgh}$ & 26.34ghi & $2.40 \mathrm{jk}$ & $3.73 \mathrm{hi}$ & 35.66 \\
\hline G3 & $24 \mathrm{gh}$ & $134 \mathrm{def}$ & $141 \mathrm{def}$ & $38 \mathrm{k}$ & $28.19 \mathrm{ab}$ & $28.31 \mathrm{a}$ & $2.28 \mathrm{jk}$ & $4.92 \mathrm{de}$ & 53.66 \\
\hline G4 & $61 \mathrm{de}$ & 112ghij & $217 \mathrm{ab}$ & $87 \mathrm{~cd}$ & $28.25 \mathrm{a}$ & $27.87 \mathrm{a}$ & $2.72 \mathrm{ij}$ & $4.08 \mathrm{gh}$ & 33.33 \\
\hline G5 & $20 \mathrm{gh}$ & $101 \mathrm{hijk}$ & $182 \mathrm{bcd}$ & $72 \mathrm{ef}$ & $25.46 \mathrm{ij}$ & $26.02 \mathrm{hi}$ & $3.17 \mathrm{hi}$ & $3.31 \mathrm{i}$ & 4.24 \\
\hline G6 & $4 \mathrm{~h}$ & $83 \mathrm{k}$ & $155 \mathrm{cde}$ & 50hij & $28.51 \mathrm{a}$ & $27.50 \mathrm{bc}$ & $2.17 \mathrm{k}$ & $4.47 \mathrm{efg}$ & 51.42 \\
\hline G7 & $12 \mathrm{~h}$ & $137 \mathrm{de}$ & $227 \mathrm{a}$ & $77 \mathrm{def}$ & $26.55 \mathrm{ef}$ & 26.79defg & $2.04 \mathrm{k}$ & $4.96 \mathrm{de}$ & 58.87 \\
\hline G8 & $12 \mathrm{~h}$ & 104hij & $93 \mathrm{gh}$ & 76def & $26.80 \mathrm{de}$ & $26.35 \mathrm{ghi}$ & $2.27 \mathrm{jk}$ & $4.29 \mathrm{fg}$ & 47.1 \\
\hline G9 & $37 \mathrm{fg}$ & $92 \mathrm{jk}$ & $114 \mathrm{efg}$ & 74def & $27.71 b c$ & $28.05 \mathrm{a}$ & $4.22 \mathrm{ef}$ & $6.15 b$ & 31.38 \\
\hline G10 & $65 \mathrm{cde}$ & 94ijk & 89ghi & $52 \mathrm{hi}$ & $25.93 \mathrm{hi}$ & $26.66 \mathrm{efg}$ & $3.24 \mathrm{gh}$ & $4.13 \mathrm{fgh}$ & 21.64 \\
\hline G11 & $47 \mathrm{ef}$ & $160 \mathrm{bc}$ & $193 a b c$ & $114 \mathrm{~b}$ & $26.46 \mathrm{efg}$ & $26.40 \mathrm{fgh}$ & $3.72 \mathrm{fg}$ & $6.10 \mathrm{~b}$ & 38.94 \\
\hline G12 & $97 \mathrm{ab}$ & $180 \mathrm{ab}$ & $123 \mathrm{efg}$ & $85 \mathrm{cde}$ & $26.62 \mathrm{ef}$ & $26.75 \mathrm{defg}$ & $4.10 \mathrm{ef}$ & $5.38 \mathrm{~cd}$ & 23.79 \\
\hline G13 & $76 \mathrm{~cd}$ & $137 d$ & $143 \mathrm{de}$ & $121 \mathrm{ab}$ & $28.30 \mathrm{a}$ & $27.95 \mathrm{a}$ & $5.47 \mathrm{ab}$ & $6.72 \mathrm{a}$ & 18.57 \\
\hline G14 & $59 \mathrm{de}$ & $143 \mathrm{~cd}$ & 84ghi & $95 \mathrm{c}$ & $26.73 \mathrm{def}$ & $27.01 \mathrm{cde}$ & $4.37 \mathrm{de}$ & $5.38 \mathrm{~cd}$ & 18.77 \\
\hline G15 & 63cde & $135 \mathrm{def}$ & 90ghi & $112 b$ & $26.86 \mathrm{de}$ & $26.72 \mathrm{defg}$ & $5.80 \mathrm{a}$ & $6.72 \mathrm{a}$ & 13.62 \\
\hline G16 & $83 b c$ & $170 \mathrm{ab}$ & $123 \mathrm{efg}$ & $131 \mathrm{a}$ & $26.42 \mathrm{efgh}$ & $26.97 \mathrm{cdef}$ & $4.11 \mathrm{ef}$ & $4.90 \mathrm{de}$ & 16.12 \\
\hline G17 & $65 \mathrm{cde}$ & 97hijk & $100 \mathrm{fgh}$ & $71 \mathrm{fg}$ & $26.36 \mathrm{efgh}$ & $27.12 \mathrm{cde}$ & $4.61 \mathrm{cde}$ & $5.64 b c$ & 18.26 \\
\hline G18 & $70 \mathrm{~cd}$ & $116 \mathrm{efgh}$ & $95 \mathrm{gh}$ & $58 \mathrm{gh}$ & $27.20 \mathrm{~cd}$ & $27.26 \mathrm{~cd}$ & $4.49 \mathrm{de}$ & $5.93 b c$ & 24.28 \\
\hline G19 & $82 \mathrm{bc}$ & 114 fghi & $57 \mathrm{hi}$ & 43ijk & 26.34efgh & $26.73 \mathrm{defg}$ & $4.78 \mathrm{~cd}$ & $5.53 \mathrm{c}$ & 13.56 \\
\hline G20 & $101 \mathrm{ab}$ & $186 a$ & $98 \mathrm{gh}$ & $51 \mathrm{hij}$ & $26.25 \mathrm{fgh}$ & $26.23 \mathrm{ghi}$ & $4.27 \mathrm{de}$ & $5.93 b c$ & 27.99 \\
\hline G21 & $108 \mathrm{a}$ & 126defg & $48 \mathrm{i}$ & $34 \mathrm{k}$ & $25.99 \mathrm{gh}$ & $25.80 \mathrm{i}$ & $4.99 \mathrm{bc}$ & $5.53 \mathrm{c}$ & 9.68 \\
\hline G22 & $24 \mathrm{gh}$ & 99hijk & $150 \mathrm{cde}$ & 41ijk & $23.63 \mathrm{k}$ & $23.07 \mathrm{k}$ & $2.31 \mathrm{jk}$ & $5.38 \mathrm{~cd}$ & 57.06 \\
\hline BNT & 20.4 & 21.25 & 43.0 & 13.39 & 0.53 & 0.57 & 0.52 & 0.56 & \\
\hline r Hasil & $0.74 * *$ & $0.42 *$ & $-0.58^{* *}$ & $0.27 *$ & 0.14 & 0.13 & 1.0 & 1.0 & \\
\hline
\end{tabular}

Keterangan: Angka yang diikuti huruf yang sama pada kolom yang sama tidak berbeda nyata berdasarkan uji Beda Nyata Terkecil (BNT) pada taraf 5\%; GI = jumlah gabah isi per malai; $\mathrm{GH}=$ jumlah gabah hampa per malai; $\mathrm{B} 1,000=$ bobot 1,000 butir gabah; HSL $=$ hasil; $\Delta \mathrm{HSL}=$ penurunan hasil; $\mathrm{r}$ Hasil $=$ korelasi terhadap hasil; $*=$ berkorelasi nyata dan $* *=$ berkorelasi sangat nyata 
MR-3-3 (G5) sebesar 4.24\%, sedangkan semua genotipe IPB107F (G12-G19) mengalami penurunan hasil yang lebih rendah dibandingkan varietas Tapus (G20) sebesar 27.99\%. Hal yang menarik dari percobaan ini adalah varietas IR64 (G21) yang merupakan varietas padi sawah hanya mengalami penurunan hasil yang rendah pada kondisi cekaman rendaman stagnan, sedangkan varietas pembanding sawah lainnya IR42 (G22) mengalami penurunan hasil hingga $57 \%$. Rendahnya penurunan hasil varietas IR64 (G21) pada kondisi cekaman rendaman stagnan dapat juga memberikan penjelasan terhadap genotipe BP1027F-PN-1-2-1-KNMR-3-3 (G5) yang mengalami penurunan hasil terendah karena sifat tersebut diduga diturunkan dari IR64 (G21) yang merupakan salah satu tetua dari galur tersebut, yaitu merupakan hasil persilangan antara varietas lokal Pucuk dengan varietas IR64 (Tabel 1).

\section{Korelasi terhadap Hasil}

Analisis korelasi antara karakter yang diamati terhadap hasil menunjukkan bahwa tidak ada karakter agronomi yang berkorelasi positif nyata terhadap hasil. Hanya karakter umur berbunga $50 \%$ yang memiliki korelasi sangat nyata terhadap hasil, namun bernilai negatif $\left(\mathrm{r}=-0.51^{* *}\right)$. Komponen hasil yang paling berkontribusi terhadap hasil adalah jumlah gabah isi $(\mathrm{r}=0.74 * *)$ dan jumlah gabah hampa per malai ( $\mathrm{r}$ $\left.=-0.58^{* *}\right)$, sedangkan bobot 1,000 butir memiliki korelasi yang rendah terhadap hasil di lingkungan tercekam rendaman $(\mathrm{r}=0.14)$ maupun di lingkungan optimum $(\mathrm{r}=0.13)$.

Kemampuan pemanjangan batang yang merupakan strategi adaptasi tanaman padi pada lingkungan tercekam rendaman stagnan ternyata tidak memiliki korelasi yang tinggi terhadap hasil. Percobaan ini menunjukkan rata-rata laju pemanjangan batang hanya memiliki koefisien korelasi -0.11 , sedangkan pemanjangan batang memiliki koefisien korelasi -0.29. Nilai negatif menunjukkan semakin tinggi pemanjangan batang, maka hasil akan semakin rendah. Tabel 3 menunjukkan bahwa genotipe-genotipe IPB107F (G12G19) yang mempunyai hasil cukup tinggi pada lingkungan tercekam rendaman stagnan ternyata rata-rata kemampuan pemanjangan batangnya relatif lebih rendah dibandingkan genotipe lainnya, namun masih lebih tinggi dibandingkan varietas pembanding IR64 (G21) setinggi $39.3 \mathrm{~cm}$ dan IR42 (G22) setinggi $36.7 \mathrm{~cm}$. Pemanjangan batang yang terlalu tinggi, selain menyebabkan kerebahan, juga menyebabkan gabah lebih mudah terserang burung. Hal ini hanya terjadi pada genotipe IR41410-6-3-3-1-2 (G1) karena memang tinggi tanaman dari galur ini berbeda cukup jauh dengan galur-galur yang tinggi lainnya (G2, G5, G6, G13 dan G22), yaitu minimal sekitar $20 \mathrm{~cm}$, sehingga jumlah gabah hampa per malainya cukup tinggi dan mengalami penurunan hasil ( $\Delta \mathrm{HSL}$ ) hingga $50.87 \%$

Berdasarkan hasil percobaan ini terlihat bahwa karakter yang memiliki korelasi tertinggi dan sangat nyata terhadap hasil adalah jumlah gabah isi $\left(\mathrm{r}=0.74^{* *}\right)$ dan umur berbunga $50 \%$ namun korelasinya negatif $(\mathrm{r}=-0.51 * *)$, artinya semakin cepat umur berbunga maka hasilnya akan semakin tinggi. Informasi ini dapat menjadi pertimbangan pemulia dalam penentuan strategi seleksi untuk mendapatkan galur padi yang berdaya hasil tinggi di daerah rendaman stagnan. Hal ini dapat terlihat dari genotipe yang memiliki hasil tertinggi pada lingkungan tercekam rendaman stagnan, yaitu IPB107-F-5-1-1 (G13) sebesar 5.47 ton ha-1 dan IPB107-F82-2-1 (G15) sebesar 5.80 ton $\mathrm{ha}^{-1}$ dengan penurunan hasil dibawah 20\%, masing-masing hanya sebesar $18.57 \%$ (G13) dan 13.62\% (G15). Umur berbunga kedua galur tersebut terbilang cepat yaitu masing-masing 86 HSS (G13) dan 87 HSS (G15). Selain itu, jumlah gabah isi per malai kedua galur tersebut termasuk tinggi, yaitu masing-masing 76 butir (G13) dan 63 (G15), sedangkan karakter agronomi maupun komponen hasil lainnya tidak berkorelasi terhadap hasil.

\section{KESIMPULAN}

Genotipe yang memiliki hasil tertinggi pada lingkungan tercekam rendaman stagnan adalah IPB107-F-51-1 (G17) sebesar 5.47 ton ha-1 dan IPB107-F-82-2-1 (G15) sebesar 5.80 ton ha $^{-1}$ dengan penurunan hasil di bawah $20 \%$. Respon genotipe padi terhadap cekaman rendaman stagnan adalah mengalami pertambahan tinggi tanaman, umur berbunga $50 \%$, umur panen, jumlah gabah hampa per malai dan kemampuan pemanjangan batang, sedangkan jumlah anakan produktif dan jumlah gabah isi per malai mengalami penurunan. Kemampuan pemanjangan batang sebagai strategi adaptasi tanaman padi terhadap cekaman rendaman stagnan ternyata tidak berkorelasi terhadap hasil.

\section{UCAPAN TERIMA KASIH}

Penulis mengucapkan terima kasih atas bantuan dana penelitian dari Hibah Kompetensi, Ditjen Pendidikan Tinggi-Kementerian Pendidikan Nasional tahun 2011 No. 375/SP2H/PP/Dit.Litabmas/ IV/2011 kepada Dr. Ir. Hajrial Aswidinnoor, M.Sc; dan I-MHERE B.2.C. IPB tahun 2011 No. 12/13.24.4/SPP/I-MHERE/2011 kepada Dr. Ir. Hajrial Aswidinnoor, M.Sc.

\section{DAFTAR PUSTAKA}

Collard, B.C.Y., E.M. Septiningsih, S.R. Das, J.J. Carandang, A.M. Pamplona, D.L. Sanchez, Y. Kato, G. Ye, J.N. Reddy, U.S. Singh, K.M. Iftekharuddanla, R. Venuprasad, C.N. Vera-Cruz, D.J. Mackill, A.M. Ismail. 2013. Developing new flood-tolerant varieties at the IRRI. SABRAO J. Breed Genet. 45:42-56.

Hattori, Y., K. Nagai, H. Mori, H. Kitano, M. Matsuoka, M. Ashikari. 2008. Mapping of three QTLs that regulate internode elongation in deepwater rice. Breed. Sci. 58:39-46.

Hattori, Y., K. Nagai, S. Fukugawa, X.J. Song, R. Kawano, H. Sakakibara, J. Wu, T. Matsumoto, A. Yoshimura, H. Kitano, M. Matsuoka, H. Mori, M. Ashikari. 2009. The ethylene response factors Snorkell and Snorkel2 allow rice to adapt to deep water. Nature 460:10261030 . 
Hattori, Y., K. Nagai, M. Ashikari. 2011. Rice growth adapting to deepwater. Curr. Opinion Plant Biol. 14:100-105.

Hirabayashi, Y., R. Mahendran, S. Koirala, L. Konoshima, D. Yamazaki, S. Watanabe, H. Kim, S. Kanae. 2013. Global flood risk under climate change. Nat. Clim. Change 3:816-821.

Kuswantoro, H. 2011. Response of soybean genotypes to waterlogging. J. Agron. Indonesia 39:19-23.

Mackill, D.J., A.M. Ismail, A.M. Pamplona, D.J. Sanchez, J.J. Carandang, E.M. Septiningsih. 2010. Stress tolerant rice varieties for adaptation to a changing climate. Crop Env. Bioinf. 7:250-257.

Mallik S., S.N. Sen, S.D. Chatterjee, S. Nandi, A. Dutta, S. Sarkarung. 2004. Sink improvement for deepwater rice. Curr. Sci. 87:1042-1043.

Nugraha, Y., G.V. Vergara, D.J. Mackill, A.M. Ismail. 2013. Parameter genetik beberapa karakter dan korelasinya terhadap gabah dalam kaitannya dengan adaptasi tanaman padi terhadap kondisi rendaman stagnan. J. Penel. Pert. 32:74-82.
Septiningsih, E.M., A.M Pamplona, D.J. Sanchez, C.N. Neeraja, G.V. Vergara, S. Heuer, A.M. Ismail, D.J. Mackill. 2009. Development of submergence tolerant rice cultivars: The Sub1 locus and beyond. Ann Bot. 103:151-160.

Singh, S., D.J. Mackill, A.M. Ismail. 2011. Tolerance of longer-term partial stagnant flooding is independent of the Sub1 locus in rice. J. Field Crops Res. 121:311323.

Suwarno, Suhartini, M. Fatchurochim, E. Lubis, R. Sismiyati, A.R. Isdianto, A. Kaher. 1996. Perbaikan varietas padi pasang surut, sulfat masam dan gambut serta rawa lebak. Laporan Akhir Riset Unggulan Terpadu (RUT) I. Puslitbangtan. Bogor.

Yullianida, A. Hairmansis, B. Kustianto, Supartopo. 2011. Kemampuan pemanjangan batang padi rawa. hal. 167-177. Dalam A.A. Daradjat, B. Suprihatno, Satoto, S.E. Baehaki, Sudir (Eds.). Prosiding Seminar Ilmiah Hasil Penelitian Padi Nasional. Sukamandi 24 November 2010. 